\title{
Availability of Information about Sustainable Bioenergy Technologies: The Agro-Energy Tree of Knowledge
}

\author{
José Gilberto Jardine ${ }^{1}$, Esdras Sundfeld ${ }^{2}$, Frederico Ozanan Machado Durães ${ }^{2}$ \\ ${ }^{1}$ Embrapa Informática Agropecuária, Computational Biology, Campinas, Brasil \\ ${ }^{2}$ Embrapa Agroenergia, Brasília, Brasil \\ Email: Jose.jardine@embrapa.br
}

Received July 10, 2013; revised August 3, 2013; accepted September 2, 2013

Copyright (C) 2013 José Gilberto Jardine et al. This is an open access article distributed under the Creative Commons Attribution License, which permits unrestricted use, distribution, and reproduction in any medium, provided the original work is properly cited.

\begin{abstract}
In addition to the efforts undertaken by research institutions to generate new knowledge and technologies, it is also necessary to promote the results of this research. Specifically, there is a need for an information system that aggregates, organizes and systematizes information about agro-energy technology and makes it available on the Internet. Despite the abundance of information circulating on the internet in Brazil, a specific method for sharing valid scientific and technological information of practical interest, such as technical guidance and recommendations for processing various materials and production technologies for various forms of agro-energy, has not yet been established. This article presents the Agro-energy Tree of Knowledge, a tool developed by Embrapa to enable web access to comprehensive information about bioenergy production systems applied in different regions and conditions, in addition to texts, publications, statistical data about production and economic markets and information links related to agro-energy.
\end{abstract}

Keywords: Clean Energy; Ethanol; Biodiesel; Renewable Energy

\section{Introduction}

The global energy matrix is still strongly biased towards fossil carbon sources, with $80 \%$ of total energy use relying on fossil fuels, including 36\% oil, 23\% coal and $21 \%$ gas. There are many studies demonstrating that fossil fuels will continue to be depleted over the next four to five decades, highlighting the need to seek alternative sources of energy [1]. The ongoing conflict in the Middle East, where approximately $80 \%$ of the world's known oil reserves are located, causes instability in the supply of oil and fluctuations in fossil fuel prices, forcing many countries to seek fuel alternatives that reduce their dependence on oil imports $[2,3]$. The growing concern for the environmental impacts of fossil fuel burning calls into question the sustainability of the current global pattern of energy consumption. The Kyoto Protocol calls for the reduction of $\mathrm{CO}_{2}$ and other gases that cause global warming to levels 5.2\% lower than those recorded in 1990, and this goal is set to be achieved during the period from 2008-2012. From an environmental point of view, the production of biofuels is an alternative to fossil fuel consumption that reduces the emission of greenhouse gases, helping to mitigate the effects of possible global warm- ing. It is included in the Kyoto Protocol and is the only currently existing mechanism for encouraging emission reductions in the international arena. All of these factors, which vary from country to country, are making new sources of biomass energy more economically feasible. Interest in the use of ethanol, biodiesel, charcoal, biogas and energy from agricultural waste is increasing in many countries, and there is no doubt that biofuels will occupy a prominent position in the global economy in the near future. Biofuels are only one segment of the bioenergy industry, which also includes charcoal, biogas, firewood and the cogeneration of electricity and heat from biomass [4-6].

While bioenergy is very important, it is only one of the many types of services and products derived from sustainable agroecosystems and the world's biodiversity, which include native forests and nature reserves, plantations, perennial crop fields, seasonal crops and pastures. Cane sugar is the second largest source of renewable energy in Brazil, accounting for $12.6 \%$ of the current energy matrix when considering the ethanol fuels and the cogeneration of electricity from bagasse [3]. Ethanol, which is used in the chemical industry, in beverages and as fuel, is the main type of bioenergy used in the world 
[7].

For biodiesel, the major centers of production and consumption are in the European Union (mainly Germany, France and Italy). The EU provides subsidies to encourage the planting of agricultural raw materials in unexplored areas, which amount to a greater than $90 \%$ exemption from taxes. About half of the production capacity for biodiesel in Europe is in Germany, which is the largest producer of biodiesel and mainly uses raw canola.

These countries have adopted laws that encourage the use of biodiesel as an oxygenator in petroleum oil at a proportion of 5\%. In Brazil, after years of research on the production and use of biodiesel, this fuel has recently ceased to be purely experimental. First, federal law does not mandate the addition of biodiesel to diesel oil sold in the country, but it does authorize fuel distributors to add $2 \%$ biofuel to each liter of diesel oil sold domestically. However, prior to establishing an obligatory addition of biodiesel, Law No. 11.097 (January 13, 2005) required $2 \%$ inclusion of biodiesel starting in 2008 , increasing to $5 \%$ in 2013 [6,14].

Waste from agricultural production and agro-industry can be converted into different forms of secondary energy, such as briquettes, biogas and bio-fertilizers. The first cycle of biogas in Brazil lasted 80 years. Several difficulties, especially with the materials used in the digesters at the time, led to the equipment to fall into disuse until the early 2000s. Brazil is particularly wellsuited for the production of energy from forest bio-mass because of its humid tropical climate, available land, abundant rural labor force, lack of job opportunities and sufficiently advanced industrial and technological levels. Sustainable management of reforestation projects can be used to increase the productivity of future forests for energy. The overall objective of the tree of knowledge is to organize information, knowledge and technology about agro-energy generated by Embrapa and other public research or educational institutions to improve the process of technology transfer [8,9]. The purpose of the system is to increase access to agro-energy information in real time via the web for various segments of civil society and improve the competitiveness of Brazilian agribusiness.

\section{Methods}

\section{The Agro-Energy Tree of Knowledge}

The methodology for the development of the agro tree of knowledge was based on pre-existing methods recommended for the development of a tree of knowledge available at Embrapa Information Agency. This methodology is being implemented by an editorial team made up of members from within the partner institutions and in-cludes a technical editor, assistant editors (two to three researchers or technicians), agro-energy specialists, information professionals and computer and communications professionals $[10,11]$.

The technical editor and assistant editors are responsible for designing and creating the structure for the tree of knowledge, selecting the publications to include, defining the scope of the informational content, and processing and publishing the content created by us. The editors are also responsible for ensuring the quality of the content of the tree of knowledge, which is to be published on the official website of the Embrapa Information Agency. The information professional is responsible for both pre-cataloging and cataloging the information resources. The IT professional is responsible for activities related to the use and maintenance of software, as well as making small adjustments to customize the details of computer desktops if necessary. The communications professional is responsible for ensuring the appropriateness of the language of the web content and coordinating the work with the Embrapa Information Agency.

The main steps of the methodological procedure employed in the project [10] are the following: 1) designing the agro-energy tree of knowledge in Agro; 2) structuring the tree of knowledge in Agro; 3) the selection, pre-listing and cataloging of information resources; 4) drafting and editing the informational content (allocated to the nodes of the tree of knowledge); and 5) publication of the tree of knowledge on the official website of the Embrapa Information Agency. Please see Figure 1 (Workflow of the construction of the Agro-energy Tree of Knowledge).

The design of the tree of knowledge requires that the publishers have full control over Agro to ensure that the items and sub-items (nodes and sub-nodes) line up systematically and hierarchically. For the handling and preparation of the structure of the tree of knowledge, the tools HiperEditor and Hypervisual [11-13] were used to visualize the information in hyperbolic tree format according to the needs and specifications of the Technical Editor.

For the development of content, the pre-cataloging and cataloging of information resources and the publication of the tree of knowledge, the content management system of the Embrapa Information Agency was used. This system has specific modules for each task, detailed by Santos et al. [10]. Each node of the tree of knowledge unfolds into items and/or sub-items (also called as sub-nodes), which contain basic information including the title, author and text. At the end of each node, additional information resources (images, text, videos, audio files, etc.) are included to supplement the information provided in the node. The content was prepared in accordance with the recommendations of Guimarães Filho 
et al. [11]. The text in the nodes of the agro-energy tree was compiled from information available at research institutions. For this step, it was necessary to map the areas and activities, as well as the products, technologies and services, generated by these institutions. The precataloging and cataloging of information resources was completed in accordance with specific recommendations for the descriptive analysis of the information contained in the Cataloging Handbook $[13,15]$.

\section{Results and Discussion}

The tree of knowledge with its nodes and subnodes can be seen in Figures 2-4, below. The main nodes (biodiesel, ethanol, waste, forestry, environment, socioeconomics, public policy, national level and PD \& I events) are arranged on the first level of the tree's hierarchical structure. They correspond to major issues related to agroenergy and contain information about the raw materials

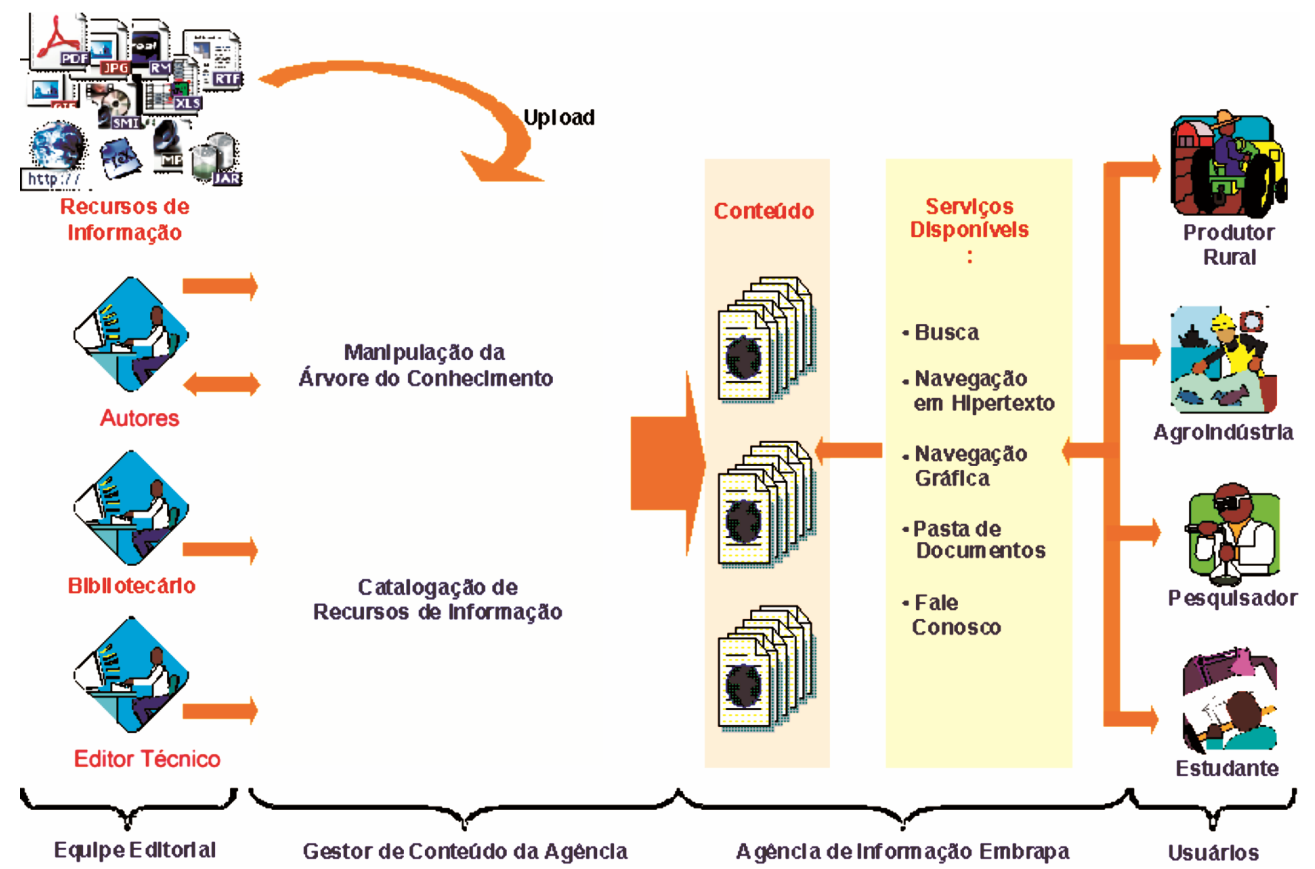

Figure 1. Workflow of the construction of the Agro-energy Tree of Knowledge. Source: adapted from Santos et al. [16].

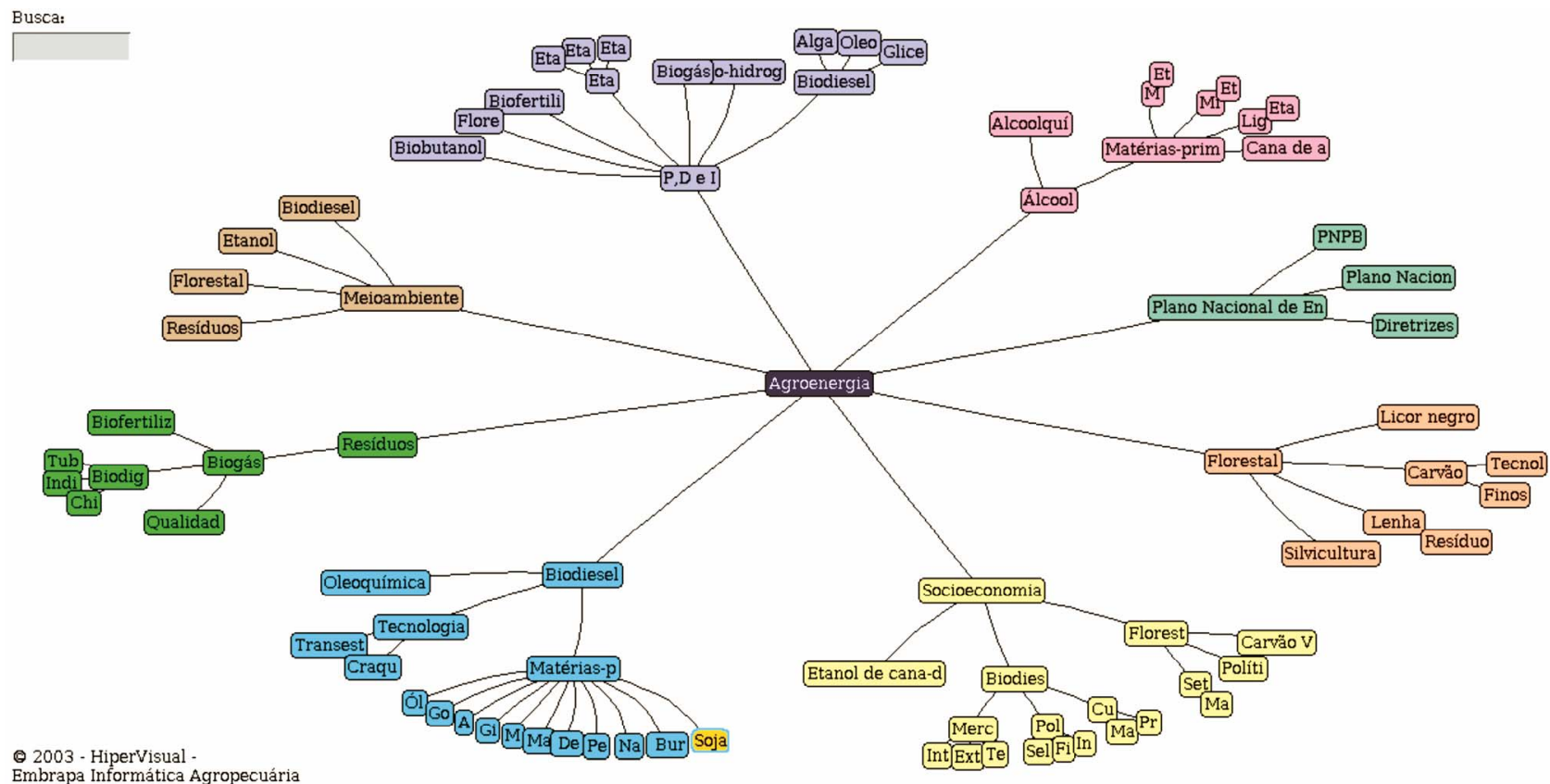

Figure 2. Centered view of the Agro-energy Tree of Knowledge. 


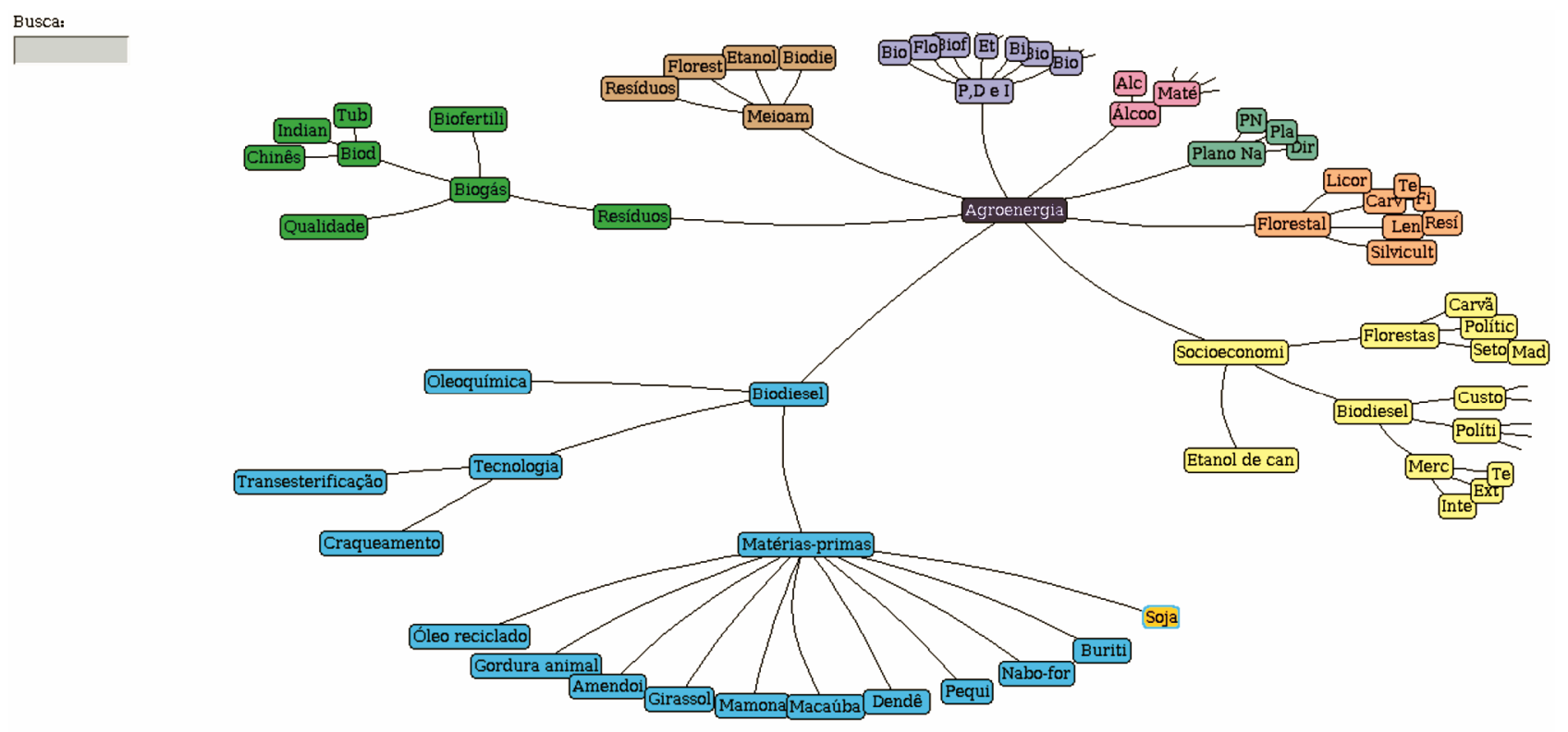

2003 - HiperVisual

Embrapa Informática Agropecuária

Figure 3. The Agro-energy Tree of Knowledge with the visual emphasis shifted to the biodiesel node.

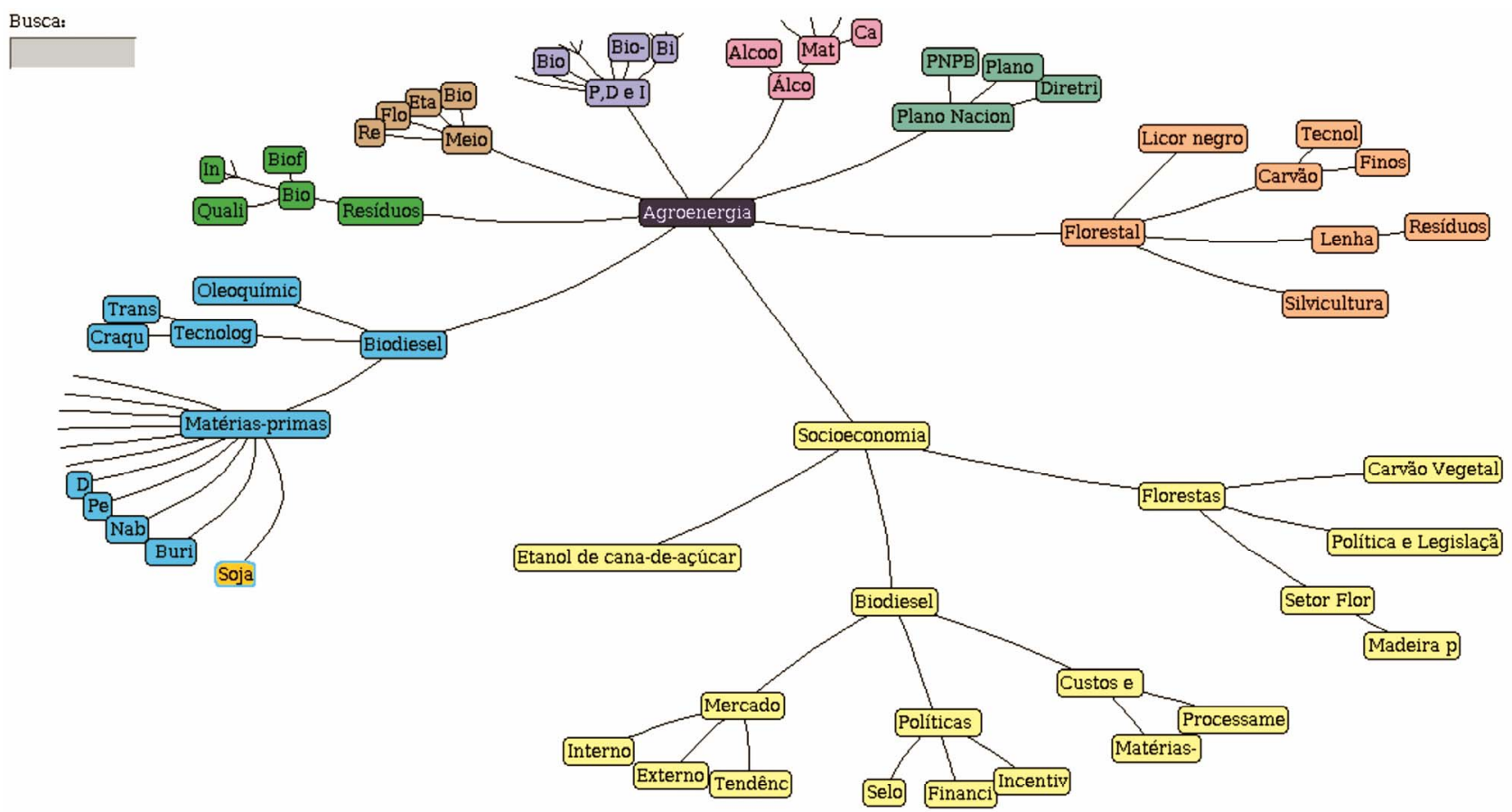

(2) 2003 - HiperVisual -

Embrapa Informática Agropecuária

Figure 4. The Agro-energy Tree of Knowledge with the visual emphasis shifted to the socioeconomics node.

and processes used to produce the various forms of bioenergy, government policies, production costs, environmental impacts and future prospects. Stemming from these main nodes, the corresponding sub-nodes are aligned systematically and hierarchically (Figure 1).

The construction of the agro-energy tree of knowledge presented a component of cross-sharp performance. There- fore, interaction with the corporate project manager at the Embrapa Information Agency was important for reconciling and integrating the tree content with the work of other agencies and for avoiding the duplication of efforts.

The structure of the tree resulted in a partnership between Embrapa Informática Agropecuária, Embrapa 
Agro-energy and Embrapa Information Technology. The text for the nodes of the tree was compiled from information that was available from research institutions. Initially, the information was supplied by the research units of Embrapa for identifying new solutions, technologies and projects in progress. However, it was very important for Embrapa to form partnerships with other research institutions, universities and private businesses to define and formalize the appropriate legal instruments for the use of information on agro-energy that is generated by these external institutions.

\section{Conclusion}

It is predicted that the structure of the agro-energy tree of knowledge will make it possible to organize, store and make available the full range of information and technology generated by research institutions in Brazil in the future. The agro-energy tree of knowledge will make the most significant efforts undertaken by these institu- tions known to the public. Another expected outcome is the provision of technological information services with value-added content that is updated and translated into language and formats appropriate for developers and other target audiences to run on the web. With the publication of the tree of knowledge in Agro on the official website of the Embrapa Information Agency, the use of this online tool is expected to improve the transfer of agro-energy technology among farmers and development agents. Such systems are essential to democratization and the dissemination of knowledge. The Agro-energy Tree of Knowledge can be accessed at:

http://www.agencia.cnptia.embrapa.br/gestor/agroenergia /Abertura.html

\section{REFERENCES}

[1] P. Venturi and G. Venturi, "Analysis of Energy Comparison for Crops in European Agricultural Systems,” Biomass and Bioenergy, Vol. 25, No. 3, 2003, pp. 235255. http://dx.doi.org/10.1016/S0961-9534(03)00015-1

[2] BNDES, "Bioetanol de Cana-de-Açúcar: Energia para o Desenvolvimento Sustentável,” BNDES, Rio de Janeiro, 2008.

[3] Ministério da Agricultura, Pecuária e Abastecimento, "Plano Nacional de Agroenergia: 2006-2011," Brasília, 2005.

[4] F. J. Simioni, “Análise Diagnóstica e Prospectiva da Cadeia Produtiva de Energia de Biomassa de Origem Florestal no Planalto sul de Santa Catarina,” Tese de dou- torado, 2007.

[5] C. E. Wyman, "Handbook on Bioethanol: Production and Utilization (Applied Energy Technology Series),” Taylor \& Francis, Washington, 1996.

[6] F. O. T. Mello, L. F. Paulillo and C. E. F .Vian, “O Biodiesel No Brasil: Panorama, Perspectivas e Desafios Informações Econômicas, perspectivas e Desafios, SP,” Vol. 37, No. 1, 2007, pp. 28-40.

[7] A. P. Rodrigues, "Etanol Combustível-Balanço e Perspectivas: Um Balanço de 30 Anos de Proálcool,” [S.l.]: Única, 2006.

http://www.nipeunicamp.org.br/proalcool/Palestras/16/An tonio\%20de\%20Padua\%20Rodrigues.ppt

[8] Secretaria de Gestão e Estratégia, Embrapa, "V Plano Diretor da Embrapa: 2008-2023,” Brasília, 2008.

[9] Embrapa Informática Agropecuária, "IV Plano Diretor da Embrapa Informática Agropecuária 2008-2011-2023,” Embrapa Informação Tecnológica, Campinas, 2008.

[10] Embrapa Informática Agropecuária, “Agência de Informação Embrapa: Ambiente Web para Transferência de Tecnologia,” Embrapa Informação Tecnológica, Campinas, 2005.

[11] C. Guimarães Filho, D. Werneck, M. R. Carneiro, M. A. Telles, R. C. Rosinha and R. V. Cobre, "Recomendações báSicas para a Elaboração do Conteúdo das Árvores do Conhecimento da Agência de Informação Embrapa. Brasília,” Embrapa Informação Tecnológica, 2005.

[12] A. D. Santos, L. M. S. Cunha da, M. I. F. Souza and M. F. Moura, "Gestor de Conteúdos da Agência de Informação Embrapa-Versão 1.3: Manual do Usuário,” Embrapa Informática Agropecuária (Embrapa Informática Agropecuária. Documentos, 58), 2005.

http://www.cnptia.embrapa.br/modules/tinycontent3/cont ent/2005/doc58.pdf

[13] M. das D. R. Alves, M. I. F. Souza and A. D. Santos, "Manual de Catalogação: Descrição de Recursos Eletrônicos, Versão 1.2,” Campinas: Embrapa Informática Agropecuária (Embrapa Informática Agropecuária. Documentos, 53), 2008.

http://www.cnptia.embrapa.br/modules/tinycontent3/cont ent/2005/doc53.pdf

[14] Kleffmann Group, "Perfil Comportamental e Hábitos de Mídia do Produtor Rural Brasileiro,” [Campinas]: ABMR \& A, 2005.

[15] Embrapa informática agropecuária, "HiperVisual e HiperEditor," Campinas, 2004.

[16] A. D. Santos dos, L. H. M. Oliveira and S. A. B. Cruz, “Gestor de conteúdo: Versão 1.3,” Campinas, 2013. http://agenciahome.cnptia.embrapa.br/docutos/doCuso/Cu rso01/Editoracao/Gestor_de_Conteudo_Curso_Jun_2006. $\mathrm{ppt}$ 